\title{
The use of electrolyte redox potential to monitor the $\mathrm{Ce}(\mathrm{IV}) / \mathrm{Ce}(\mathrm{III})$ couple
}

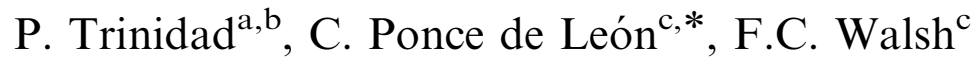 \\ ${ }^{\mathrm{a}}$ EA Technology, Capenhurst, $U K$ \\ ${ }^{\mathrm{b}}$ Apotecnia SA, El Raiguero la Villa, Beniel, 30588 Murcia, Spain \\ ${ }^{\mathrm{c}}$ Electrochemical Engineering Laboratory, Energy Technology Research Group, School of Engineering Sciences, University of Southampton, \\ Highfield, Southampton SO17 1BJ, UK
}

Received 20 July 2006; received in revised form 18 June 2007; accepted 14 July 2007

Available online 30 August 2007

\begin{abstract}
Mathematical modelling of the oxidation reduction redox potential (ORP) of an electrolyte has been carried out for a batch system comprising an electrochemical reactor and an electrolyte circuit containing a redox couple. The ORP can be useful to monitor the environmental impact of chemical species in solution that represent a risk to the environment. Considerations of four fundamental equations, namely, the Nernst equation, a mass balance, Faraday's laws of electrolysis and a first order kinetic equation, leads to an expression for the electrolyte redox potential as a function of the batch time, the electrical charge and the redox concentration. Such an expression facilitates graphical plots which can be used to estimate kinetic parameters, current efficiency and the relative redox concentration. The $\mathrm{Ce}(\mathrm{IV}) / \mathrm{Ce}(\mathrm{III})$ system has been chosen as a model reaction for electrolyte redox potential measurement in a batch recycle system consisting of a pumped flow through a divided FM01-LC parallel-plate electrochemical reactor $\left(64 \mathrm{~cm}^{2}\right.$ projected electrode area) and a well mixed tank $\left(3600 \mathrm{~cm}^{3}\right)$. The differences between experimental and model predictions are discussed.

(C) 2007 Elsevier Ltd. All rights reserved.
\end{abstract}

Keywords: Batch electrolysis; Ce(III) ion; Ce(IV) ion; Open-circuit redox potential; ORP

\section{Introduction}

The open-circuit redox potential (ORP) of an electrolyte is one of the most fundamental measurements in electrochemistry and is widely employed in laboratory studies and industrial applications (Chang et al., 2004; Nevell and Walsh, 1992; Ottewill and Walsh, 1992). Open-circuit potential measurements are also widely employed under equilibrium conditions to describe the thermodynamics of an electrochemical system (Walsh, 1992). The ORP can be used as parameter to monitor the concentration of redox species of strong environmental impact. Examples of the applications of ORP measurements include: monitoring the kinetics of an electrode process, corrosion monitoring and the control of metal finishing solutions (Ottewill and Walsh, 1992) and as an indicator of the degree of

\footnotetext{
${ }^{*}$ Corresponding author. Tel.: + 44238059 8931; fax: +442380597051.

E-mail address: capla@soton.ac.uk (C.P. de León).
}

nitrification/denitrification in biological systems (Chang et al., 2004). The electrolyte redox potential is also routinely used in redox titrations (Vogel, 1989) and can provide a useful method for monitoring the oxidant/ reductant ratio using the Nernst equation (Bard and Faulkner, 2001; Pletcher and Walsh, 1993; Walsh, 1993). ORP measurements are also of interest for measurement of species in solution during the determination of $\mathrm{pH}$, metal ion and dissolved oxygen in ion selective electrode potentiometry (Sparks, 1995).

Due to its important industrial applications, the cerium system $\mathrm{Ce}(\mathrm{IV}) / \mathrm{Ce}(\mathrm{III})$ was selected as an example for ORP measurements. The environmental impact of cerium is important during coal combustion (Seames and Wendt, 2000) and can be toxic for corn and mungbean at sufficiently high concentrations $\left(0.1-2 \mathrm{mg} \mathrm{L}^{-1}\right)$ (Diatloff et al., 1999). The metal can be hazardous when dispersed in the environment so its control and monitoring are important. 


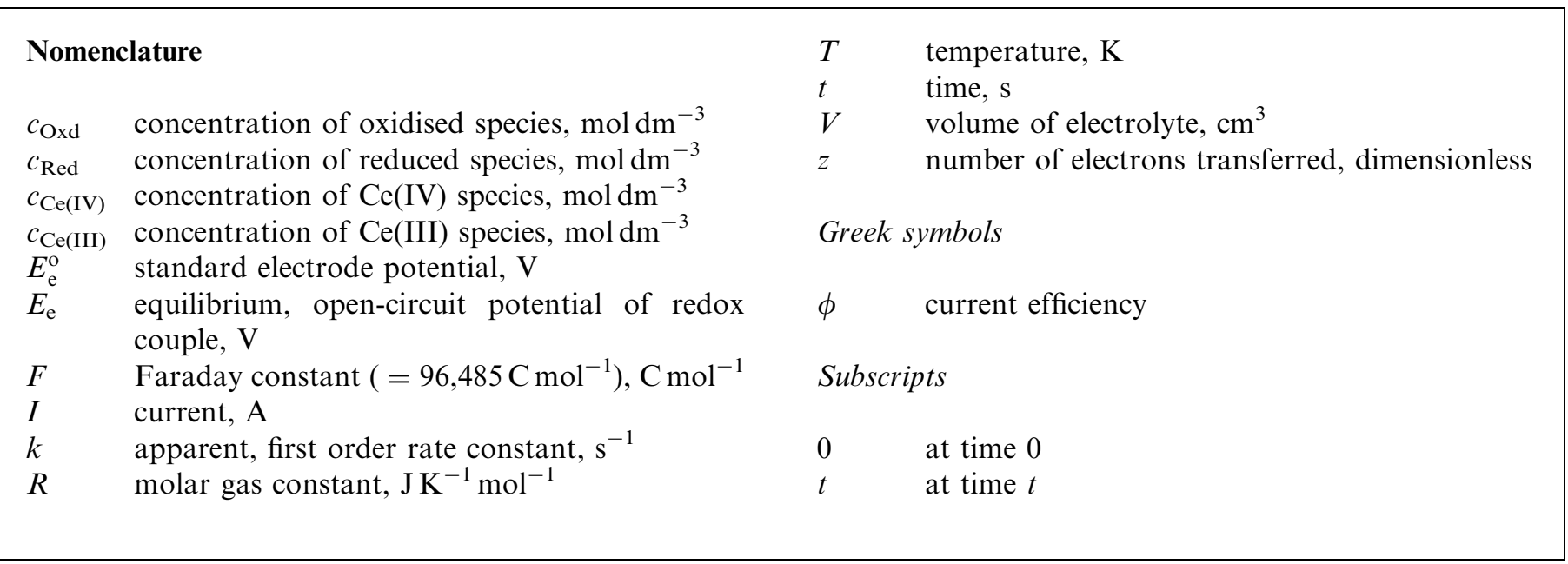

Cerium has large number of applications that include fabrication of aluminium and steel alloys (Xu, 2000), chemical oxidising agents (Liu and Huang, 2004), electrochemical destruction of aniline (Chung and Park, 2000), increasing crop yields (Hu et al., 2002), glass manufacture, catalysts, self-cleaning ovens, chemical analysis, as carbonarc lighting in the film industry and in the nuclear industry. Rare earth elements such as cerium can promote germination and enhance the resistance of crops representing a non-hormonal option to promote the floral initiation and reproductive growth of some plants (He and Loh, 2000). In the power industry, cerium can be used in energy storage electrochemical cells. For example, the redox system

$\mathrm{Ce}(\mathrm{IV})+\mathrm{e}^{-} \leftrightarrows \mathrm{Ce}(\mathrm{III})$

in combination with the $\mathrm{Zn}(\mathrm{II}) / \mathrm{Zn}(0)$ couple, is used in redox flow batteries and the performance can be monitored with an ORP probe (Ponce de León et al., 2006). The cell voltage of the $\mathrm{Zn} / \mathrm{Ce}$ system during charge is approximately $2.5 \mathrm{~V}$ and drops below $2 \mathrm{~V}$ on discharge. The system has been developed by Plurion Systems Inc. and successful operation of a cell at current densities of $400-500 \mathrm{~mA} \mathrm{~cm}^{-2}$ has been claimed (High Capacity Electrical Storage Power Conditioning Units; Liu et al., 2004).

Cerium can be monitored from aqueous solution extracted from rare earth oxides, rocks, soil, natural water, plants and animals. Based on the ORP, electrochemical probes (ORP combination electrodes) have been shown to be reliable when monitoring hazardous materials such as $\mathrm{CO}, \mathrm{CO}_{2}, \mathrm{NH}_{4}, \mathrm{SO}_{2}$, metals, organic and inorganic materials in aqueous solutions (Sparks, 1995). The ORP can be used as an on-line probe to monitor the concentration of redox species.

In this paper, an approximate procedure is used to estimate kinetic parameters, current efficiency and the batch time needed to achieve a particular conversion in a fixed volume of the batch recycle system. The continuous monitoring of the potential between an inert ( $\mathrm{Pt}$ or $\mathrm{C}$ ) electrode and an $\mathrm{Ag} / \mathrm{AgCl}$ reference electrode in a batch recycle system, where the electrochemical reaction (1) takes place, is considered. An electrochemical system consisting of a reactor, electrolyte tank and flow circuit was used. This arrangement has been treated via classical flow reactor models such as the batch reactor (BR), the plug flow reactor (PFR) with recirculation, or the continuous stirred tank reactor (CSTR) with recirculation (Ford et al., 1992; Walker and Wragg, 1977). Previous studies to monitor the concentration of electrochemical active rare earth chemicals have normally involved discontinuous chemical analysis of reactants (or products) by atomic absorption spectroscopy (AAS) (Jain et al., 2001) and high-performance liquid chromatography (HPLC) (Shuai et al., 2000) which require relatively expensive instrumentation.

\section{Theory}

Four fundamental equations have been used to establish the relationships between concentration and the ORP during the batch electrolysis:

(1) the Nernst equation to describe the redox potential of the electrolyte as function of a redox couple (Bard and Faulkner, 2001),

(2) a mass balance equation on the species taking part in the reactions (Levenspiel, 1972),

(3) Faraday's laws of electrolysis to relate chemical change to the electrical charge passed (Walsh, 1991; Bockris and Reddy, 1998), and

(4) kinetic expressions, e.g. a first order kinetic equation which is useful to describe the behaviour of a batch electrochemical system under complete mass transport control (Kiekens et al., 1981; Trinidad, 2000; Trinidad and Walsh, 1999).

For the reversible electrode process shown in reaction (1), the redox potential can be expressed using the Nernst equation as (Bard and Faulkner, 2001; Pletcher, 1991):

$E_{\mathrm{e}}=E_{\mathrm{e}}^{\mathrm{o}}+\frac{R T}{z F} \ln \left(\frac{c_{\mathrm{Ce}(\mathrm{IV})}}{c_{\mathrm{Ce}(\mathrm{III})}}\right)$ 
where $E_{\mathrm{e}}$ is the redox potential of the $\mathrm{Ce}(\mathrm{III}) / \mathrm{Ce}(\mathrm{IV})$ couple, $E_{\mathrm{e}}^{\mathrm{o}}$ the standard potential, $z$ the number of electrons, $F$ the Faraday constant, $R$ the molar gas constant, $T$ the temperature and $c_{\mathrm{Ce}(\mathrm{IV})}$ and $c_{\mathrm{Ce}(\mathrm{III})}$ are the concentrations of oxidised $\left(c_{\mathrm{Oxd}}\right)$ and reduced $\left(c_{\mathrm{Red}}\right)$ species, respectively.

For simplicity, only the reduction process will be considered; the extension to an oxidation process follows a similar analysis. Faraday's laws of electrolysis can be written as an expression for the amount of substance undergoing an electrochemical change in a constant volume $(V)$ reaction. For example, during a constant current electrolysis, the concentration of the reduced species $c_{\mathrm{Ce}(\mathrm{III})}$, produced during the batch electrolysis time, $t$, will be given by (Walsh, 1992)

$\left(c_{\text {Red }}\right)_{t}=\frac{\phi I t}{z F V}$,

where $\phi$ is the overall current efficiency and $I$ is the electrical current. Since the electroactive species are considered to exist only as oxidised or reduced species in solution, a mass balance on the oxidised species may be written as

$\left(c_{\text {Oxd }}\right)_{t}=\left(c_{\text {Oxd }}\right)_{0}-\left(c_{\text {Red }}\right)_{t}$,

where $\left(c_{\mathrm{Oxd}}\right)_{t}$ and $\left(c_{\mathrm{Oxd}}\right)_{0}$ represent the concentrations of the oxidised species at times $t$ and 0 , respectively, and $\left(c_{\operatorname{Red}}\right)_{t}$ is the concentration of the reduced species at the batch time $t$. Substituting Eq. (3) into (4), the expression for the oxidised species at time $t$ is

$\left(c_{\text {Oxd }}\right)_{t}=\left(c_{\text {Oxd }}\right)_{0}-\frac{I t}{z F V} \phi$.

Substitution of Eq. (5) into (2) leads to

$E_{\mathrm{e}}=E_{\mathrm{e}}^{\mathrm{o}}+\frac{R T}{z F} \ln \frac{\left(c_{\mathrm{Oxd}}\right)_{0}-(I t / z F V) \phi}{\left(c_{\mathrm{Red}}\right)_{0}+(I t / z F V) \phi}$.

Eq. (6) can be applied to both mass transport and charge transfer controlled reactions. In the case of a mass transport controlled reaction, the current efficiency will vary with time while in the case of charge transfer control it will remain constant (Walsh, 1993).

Under complete mass transport controlled conditions, reaction (1) shows overall first order kinetics (Bockris and Reddy, 1998) and the concentration of the oxidised species as a function of time in a constant volume, batch system can be written as

$\left(c_{\text {Oxd }}\right)_{t}=\left(c_{\text {Oxd }}\right)_{0} \exp (-k t)$,

where $k$ is the apparent first order rate constant for the concentration decay of $c_{\text {Oxd }}$ with time and $k=k_{m} A / V$, i.e. the product of mass transport coefficient and electrode area divided by a constant electrolyte volume. The concentration of the reduced species at any time can be written as

$\left(c_{\text {Red }}\right)_{t}=\left(c_{\text {Red }}\right)_{0}+\left[\left(c_{\text {Oxd }}\right)_{0}-\left(c_{\text {Oxd }}\right)_{t}\right]$.
Substituting Eq. (7) into (8) leads to

$\left(c_{\text {Red }}\right)_{\mathrm{t}}=\left(c_{\text {Red }}\right)_{0}+\left(c_{\text {Oxd }}\right)_{0}[1-\exp (-k t)]$.

Substitution of Eq. (9) into the Nernst Eq. (2) leads to

$$
\begin{aligned}
E_{\mathrm{e}}= & E_{\mathrm{e}}^{\mathrm{o}}+\frac{R T}{z F} \\
& \times \ln \left\{\frac{\left(c_{\mathrm{Oxd}}\right)_{0} \exp (-k t)}{\left(c_{\text {Red }}\right)_{0}+\left(c_{\mathrm{Oxd}}\right)_{0}[1-\exp (-k t)]}\right\} .
\end{aligned}
$$

Simplification of Eq. (10) provides the expression

$$
\begin{aligned}
E_{\mathrm{e}}= & E_{\mathrm{e}}^{\mathrm{o}}-\frac{R T}{z F} \\
& \times\left\{k t+\ln \left[\frac{\left(c_{\mathrm{Red}}\right)_{0}}{\left(c_{\mathrm{Oxd}}\right)_{0}}+(1-\exp (-k t))\right]\right\} .
\end{aligned}
$$

This equation describes a reduction process; for an oxidation process, the analogous treatment leads to

$$
\begin{aligned}
E_{\mathrm{e}}= & E_{\mathrm{e}}^{\mathrm{o}}+\frac{R T}{z F} \\
& \times\left\{k t+\ln \left[\frac{\left(c_{\mathrm{Oxd}}\right)_{0}}{\left(\mathrm{c}_{\mathrm{Red}}\right)_{0}}+(1-\exp (-k t))\right]\right\} .
\end{aligned}
$$

Eqs. (10) and (11) express the equilibrium potential of the $\mathrm{Ce}(\mathrm{III}) / \mathrm{Ce}(\mathrm{IV})$ redox couple as a function of the concentration and the reaction rate constant.

\section{Experimental details}

\subsection{Electrochemical cell}

Experiments were carried out in a batch recycle mode using the FM01-LC laboratory electrolyser and the electrolyte flow circuit shown in Fig. 1. The electrolyser is a divided, parallel-plate reactor. The electrode materials were provided by INEOS Chlor-Chemicals including a stainless steel 316, anode for "persalt" production (type $210)$ and commercially pure $(99 \mathrm{wt} \%)$ lead electrodes. Additionally, a 100 ppi reticulated vitreous carbon (RVC) cathode was used when the cell was assembled with two

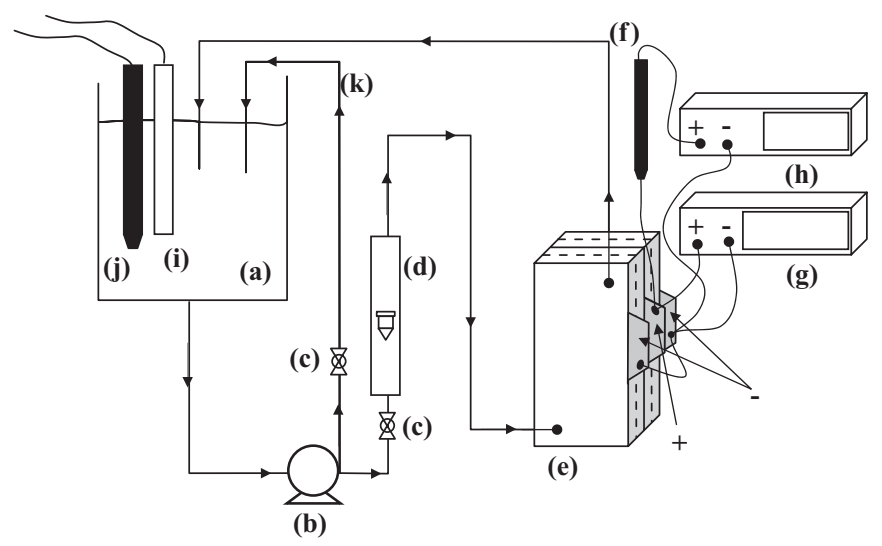

Fig. 1. Electrolyte system: (a) reservoir, (b) pump, (c) valve, (d) rotameter, (e) FM01-LC reactor, (f) SCE, (g) dc power supply, (h) high impedance digital voltmeter (dvm), (i) silica-sheathed heater, (j) mercury-in-glass thermometer and $(\mathrm{k})$ bypass flow loop. 
anodes. The cell has a projected single electrode area of $16 \times 4 \mathrm{~cm}$ filled with a routed-type polymer turbulence promoter in the electrolyte channel. The characteristics of this type of turbulence promoter and the cell characterisation for the standard reaction of the reduction of the ferricyanide ion at nickel electrodes have been described in detail by Brown et al. (1992, 1994, 1995) and by Ralph et al. (2005). A cation exchange membrane (Nafion 415) was used in the divided configuration to separate anolyte from catholyte. High impedance digital voltmeters (dvm) were used to measure the cell voltage and cathode and anode potentials versus the reference electrode. Table 1 summarises the main physical and operational characteristics of the FM01-LC cell.

\subsection{Electrolyte circuit}

The electrolyte system consisted of a PVC tank of $3600 \mathrm{~cm}^{3}$ capacity, an electrolyte circuit constructed from silicone rubber tubing of $7 \mathrm{~mm}$ internal diameter, a rotameter of $0-50 \mathrm{dm}^{3} \mathrm{~h}^{-1}$ measuring range and a magnetically coupled centrifugal pump (Totton model NEMP50/7), with a polypropylene pump head. Fine adjustments of the electrolyte flow rate were made with a precision valve (Gebr Muller valve, type 607). The temperature was maintained at $25 \pm 2{ }^{\circ} \mathrm{C}$ by a water-cooled, glass coil heat exchanger and a silica-sheathed immersion heater and measured via a mercury-in-glass thermometer. The flow rate of the heat exchanger coolant was controlled manually while the silica-sheathed heater was connected to a Eurotherm $\mathrm{T}$ controller, which incorporated a Chromel-Alumel thermocouple. Effective electrolyte mixing in the PVC tank was achieved by recirculation of the fluid through a bypass loop. The reactor was operated galvanostatically (up to $10 \mathrm{~A}$ ) using a regulated power supply (Farnell model AP60-50), and the current was measured by a standard shunt connected to a calibrated $x-y$ chart recorder.

\subsection{Methodology}

The redox potential of the electrolyte was continuously measured by a combined $\mathrm{Pt}-\mathrm{Ag} / \mathrm{AgCl}$ reference element

Table 1

Physical characteristics of the FM01-LC laboratory electrolyser

\begin{tabular}{ll}
\hline Projected electrode area, $A\left(\mathrm{~cm}^{2}\right)$ & 64 \\
Internal electrode length, $L(\mathrm{~cm})$ & 16 \\
Internal electrode height, $B(\mathrm{~cm})$ & 4 \\
Separation between electrode and membrane, $S(\mathrm{~cm})$ & 0.69 \\
Membrane & Nafion 415 \\
Gasket material & PTFE-composite \\
Spacer material & PTFE-composite \\
Gasket thickness $(\mathrm{cm})$ & 0.15 \\
Spacer thickness $(\mathrm{cm})$ & 0.39 \\
Cross-sectional area of channel for flow $\left(\mathrm{cm}^{2}\right)$ & 2.79 \\
Equivalent diameter, $d_{\mathrm{e}}=2 B S /(B+S)(\mathrm{cm})$ & 0.97 \\
Electrolyte mean linear flow velocity, $v\left(\mathrm{~cm} \mathrm{~s}^{-1}\right)$ & 17.7 \\
\hline
\end{tabular}

(ABB Kent) in saturated (ca. $3.5 \mathrm{~mol} \mathrm{dm}^{-3}$ ) $\mathrm{KCl}$ using a $\mathrm{dvm}$. A second redox potential probe used a glassy carbon rod electrode monitored by a saturated calomel electrode through a dvm.

A typical experiment involved recirculation of $1.6 \mathrm{~L}$ of electrolyte containing a known concentration of $\mathrm{Ce}(\mathrm{IV})$ and $\mathrm{Ce}(\mathrm{III})$ in $1 \mathrm{moldm}^{-3} \mathrm{H}_{2} \mathrm{SO}_{4}$ at $298 \mathrm{~K}$ using a mean linear electrolyte velocity of $17.7 \mathrm{~cm} \mathrm{~s}^{-1}$. Anhydrous $\mathrm{Ce}_{2}\left(\mathrm{SO}_{4}\right)_{3}$ and $\mathrm{Ce}\left(\mathrm{SO}_{4}\right)_{2} \cdot 4 \mathrm{H}_{2} \mathrm{O}$ (Fisher Puriss grade) were the sources of $\mathrm{Ce}(\mathrm{IV})$ and $\mathrm{Ce}(\mathrm{III})$ ions, respectively. The batch electrolysis experiments were carried out until equilibrium conditions were reached, typically up to $8 \mathrm{~h}$ for $\mathrm{Ce}(\mathrm{III})$ oxidation and $3 \mathrm{~h}$ for $\mathrm{Ce}$ (IV) reduction. Onecubic-centimetre samples of electrolyte were taken at regular time intervals to determine the concentration of $\mathrm{Ce}(\mathrm{IV})$ by chemical analysis. The concentration of $\mathrm{Ce}(\mathrm{IV})$ species was found by titration with a previously standardised $\mathrm{Fe}(\mathrm{II})$ solution, made up from diammonium iron(II) sulfate 6-hydrate (Mohr's salt; Fluka Puriss) and adjusted to $\mathrm{pH} 1$ with sulfuric acid (Fluka Puriss). This salt is a pseudo-analytical standard; solutions of $\mathrm{Fe}(\mathrm{II})$ previously standardised were compared with other solutions which were gravimetrically prepared; the difference was always found to be less than $0.4 \%$. The stability of diammonium iron(II) sulfate solutions against oxidation by atmospheric oxygen was followed over a period of 1 month and found that the concentration change was less than $0.8 \%$ after 4 days and $8.7 \%$ after 1 month. Fresh solutions were prepared every day and compared against $\mathrm{Ce}(\mathrm{IV})$ standard solutions. Since the initial concentrations of $\mathrm{Ce}(\mathrm{IV})$ and $\mathrm{Ce}(\mathrm{III})$ ions were accurately known, the concentration of $\mathrm{Ce}$ (III) was calculated from a mass balance.

\subsection{Determination of the concentration of $\mathrm{Ce}$ (III) and $\mathrm{Ce}(\mathrm{IV})$ ions}

The end-point for the titration of $\mathrm{Ce}(\mathrm{IV})$ against $\mathrm{Fe}(\mathrm{II})$ was found by using ferroin (1,10-phenanthroline-ferrous sulfate, $\mathrm{BDH})$ as a colorimetric redox indicator which contains iron in divalent state and has a characteristic red colour. In the presence of an oxidant, ferroin is oxidised to its trivalent state which is blue in colour (Vogel, 1989). Potentiometric titrations were also performed using a platinum wire $/ \mathrm{Ag} / \mathrm{AgCl}$ indicator electrode. This technique follows the redox potential of the solution; when Ce(IV) species are present, the redox potential is highly positive, as $\mathrm{Fe}(\mathrm{II})$ is added the potential becomes less positive and a very sharp change in potential occurs towards the end point. The concentration values of calculated Ce(IV) using ferroin and the potentiometric technique differ by less than $0.5 \%$. Both methods were used for the titration of the electrolyte.

The concentrations of $\mathrm{Ce}(\mathrm{III})$ and $\mathrm{Ce}(\mathrm{IV})$ ions were determined prior to the start of each experiment and only the concentration of $\mathrm{Ce}(\mathrm{IV})$ was followed through the batch reaction. The initial concentration of $\mathrm{Ce}$ (III) was 
determined by oxidation to Ce(IV) and then titrated with a standard solution of $\mathrm{Fe}(\mathrm{II})$ as previously described. During the batch electrolysis Ce(III) concentration was calculated using material balance and confirmed by oxidation to $\mathrm{Ce}(\mathrm{IV})$. Two oxidation methods were used (Vogel, 1989). In the first method, a known volume of the solution containing $0.1-0.3 \mathrm{~g}$ of cerium in $25 \mathrm{wt} \%$ sulfuric acid was treated with $2 \mathrm{~g}$ ammonium sulfate and $1 \mathrm{~g}$ analytical grade sodium bismuthate; then the solution was boiled for $10 \mathrm{~min}$. After the solution was cooled down, $50 \mathrm{~mL} 2 \%$ sulfuric acid were added, followed by filtration through a sintered glass crucible; the crucible was washed with $100 \mathrm{ml}$ of $2 \%$ sulfuric acid solution. A known volume of standard ammonium iron(II) solution was added and the excess of iron(II) salt was back-titrated with a standard potassium permanganate solution until the first appearance of a pink colour. The second oxidation method involved ammonium persulfate. The solution to be analysed, which contained $0.1-0.3 \mathrm{~g}$ of cerium and $2.5-7.5 \mathrm{~mL}$ of concentrated sulfuric acid, was treated with $1-1.5 \mathrm{~g}$ of analytical grade ammonium persulfate and 10 drops of $0.1 \mathrm{~mol} \mathrm{dm}^{-3}$ silver nitrate solution; then the solution was boiled for $10 \mathrm{~min}$ and allowed to cool down to room temperature. The resulting solution was titrated with a standard solution of $\mathrm{Fe}$ (II) using ferroin as indicator to detect the concentration of $\mathrm{Ce}(\mathrm{IV})$.

The use of sodium bismuthate in the first method was delicate and time consuming; in addition, the solution required filtering to remove excess of solid oxidant. It is believed that some amount of $\mathrm{Ce}(\mathrm{III})$ is adsorbed by the solid powder since the values of concentration using this method are normally 3\% below those found when using ammonium persulfate. The advantage of the second method is the fact that ammonium persulfate decomposed by boiling, making filtration unnecessary. Therefore, the second method using ammonium persulfate, was used.

\section{Results and discussion}

\subsection{Effect of current density}

The redox potential of the electrolyte was plotted as a function of the charge passed using Eq. (6), taking the current efficiency as a parameter in Fig. 2. The selected current efficiencies were $0.2,0.5,0.8$ and 1.0 with a total current of $10 \mathrm{~A}$. The simulated curves show that the redox potential becomes less positive as the reaction progressed and that there is a general trend towards the sigmoidal shape found in redox titrations as the current efficiency increased (Vogel, 1989). At low current efficiencies, the potential change was small but as the current efficiency increased, a sharp decline in potential starting at approximately $1.2 \mathrm{~V}$ versus $\mathrm{Ag} / \mathrm{AgCl}$ was observed. This decline indicates the total conversion of $\mathrm{Ce}(\mathrm{IV})$ to $\mathrm{Ce}(\mathrm{III})$. The current inefficiency controls the batch time by increasing the time needed for total conversion; at the lowest current

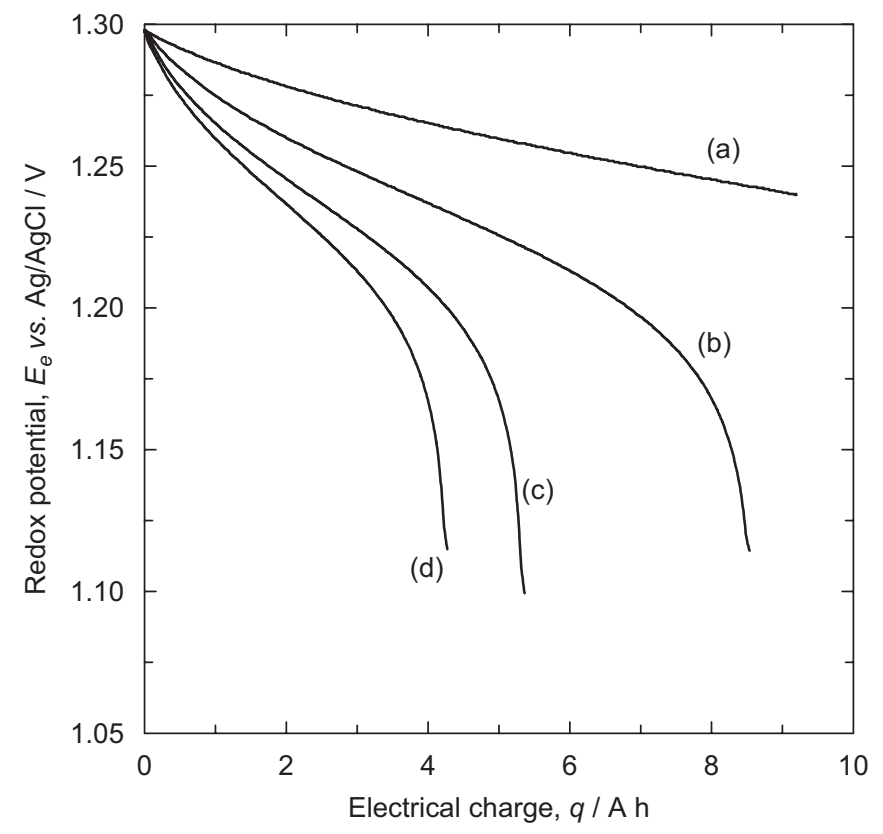

Fig. 2. Simulation of the redox potential versus charge passed using Eq. (6) for the reduction of $0.1 \mathrm{moldm}^{-3} \mathrm{Ce}(\mathrm{IV})$ with an initial concentration of $0.01 \mathrm{~mol} \mathrm{dm}^{-3} \mathrm{Ce}(\mathrm{III})$ in the batch system of Fig. 1 at $298 \mathrm{~K}$ and total current of $10 \mathrm{~A}$. Current efficiency: (a) 0.2 , (b) 0.5 , (c) 0.8 and (d) 1.0 .

efficiency, the charge was larger and the time needed for total conversion increased.

\subsection{Effect of the reaction rate constant}

Fig. 3 illustrates the use of Eq. (11) as a model prediction for the decay of electrolyte redox potential at various reaction rates for the reduction of $\mathrm{Ce}(\mathrm{IV})$ ions. The parameters used in Fig. 3 and the first order rate constant $\left(0.01-0.04 \mathrm{~min}^{-1}\right)$ are typical for the cerium system using an FM01-LC reactor (Trinidad, 2000). The rate of decrease in the redox potential, is due to the disappearance of the oxidising species, the $\mathrm{Ce}(\mathrm{IV})$ ions, and is more rapid for large values of the first order reaction rate constant. As the rate constant increases, the batch time to reduce the electrolyte redox potential values (and the conversion of $\mathrm{Ce}(\mathrm{IV})$ to $\mathrm{Ce}(\mathrm{III})$ ) diminished. In this case, the first order rate constant is fixed for the constant mass transport (hence flow + electrode geometry) conditions chosen; however, the rate constant increase with the mean electrolyte flow velocity according to $k \alpha v^{x}$, where $x \approx 0.6$ (Trinidad, 2000).

In the case of the oxidation of $\mathrm{Ce}$ (III) ions, the electrolyte redox potential increased as the batch time progressed due to the disappearance of the reductant species, as shown in Fig. 4. As the rate constant increases, the redox potential becomes more positive indicating predominance of the concentration of $\mathrm{Ce}(\mathrm{IV})$ ions. The curves shown in both Figs. 3 and 4 are symmetrical but start at different initial redox values due to the different initial concentration of the electroactive species in the electrolytes. 


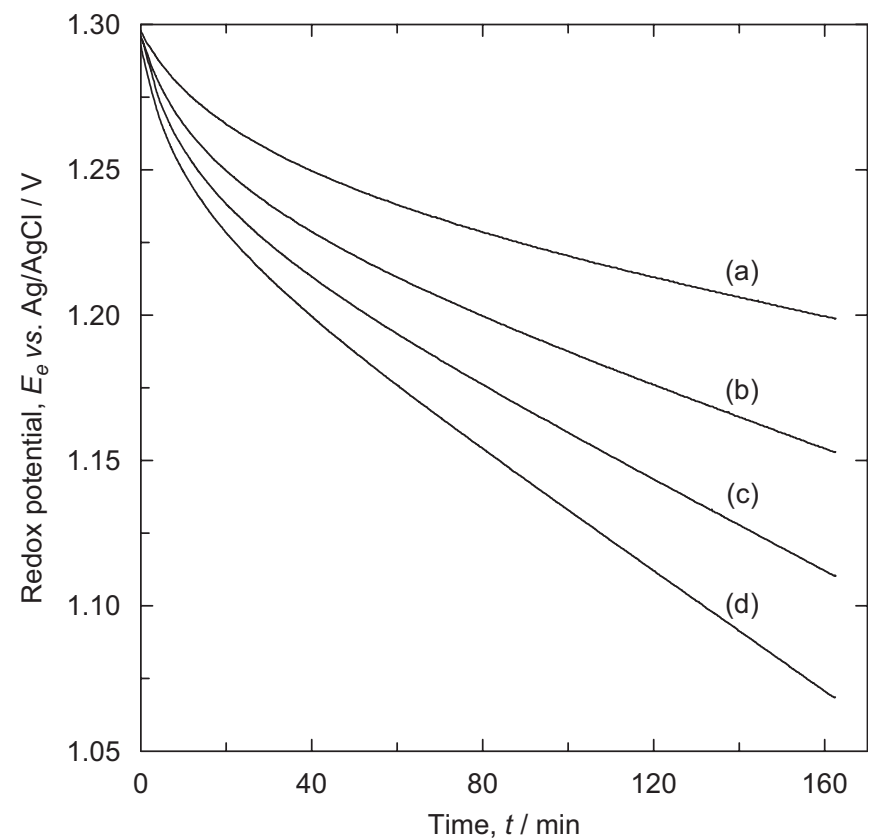

Fig. 3. Simulation of the redox potential versus time using Eq. (11) during the reduction of $0.1 \mathrm{~mol} \mathrm{dm}^{-3} \mathrm{Ce}(\mathrm{IV})$ with an initial concentration of $0.01 \mathrm{~mol} \mathrm{dm}^{-3} \mathrm{Ce}(\mathrm{III})$ in the batch system of Fig. 1 at $298 \mathrm{~K}$. First order rate constant $k$ : (a) 0.01 , (b) 0.02 , (c) 0.03 and (d) $0.04 \mathrm{~min}^{-1}$.

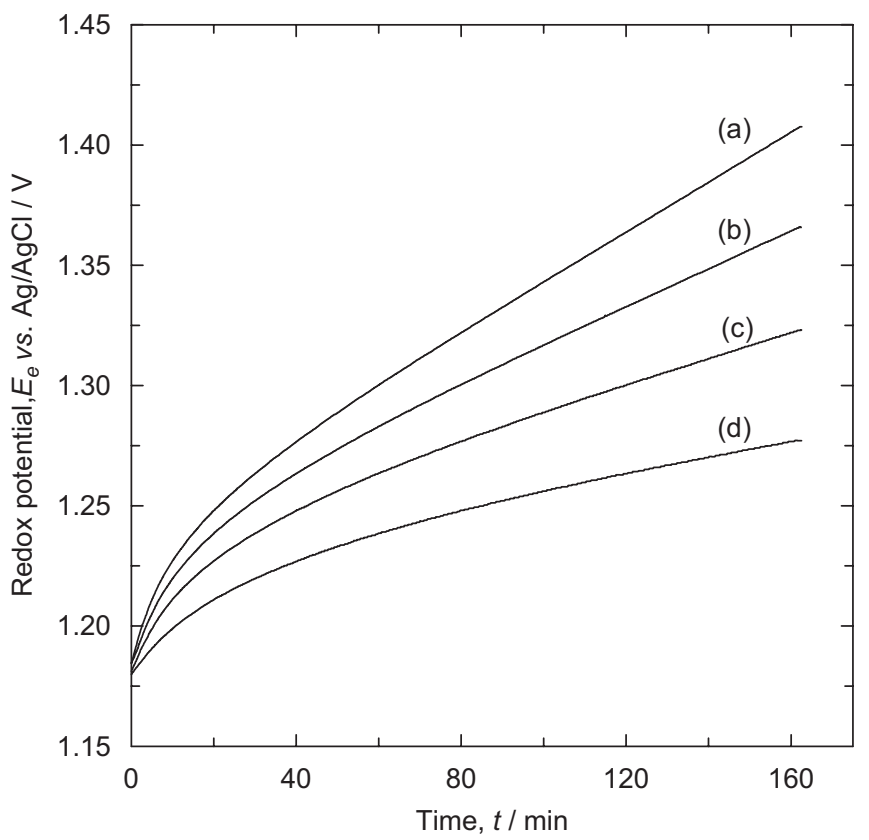

Fig. 4. Simulation of the redox potential versus time using Eq. (12) during the oxidation of $0.1 \mathrm{~mol} \mathrm{dm}^{-3} \mathrm{Ce}(\mathrm{III})$ with an initial concentration of $0.01 \mathrm{~mol} \mathrm{dm}^{-3} \mathrm{Ce}(\mathrm{IV})$ in the batch system shown in Fig. 1 at $298 \mathrm{~K}$. First order rate constant $k$ : (a) 0.04 , (b) 0.03 , (c) 0.02 and (d) $0.01 \mathrm{~min}^{-1}$.

\subsection{Predicted and experimental redox potentials during batch electrolyses}

The electrolyte redox potential was monitored during the reduction of $\mathrm{Ce}(\mathrm{IV})$ ions in a batch system. Experimental

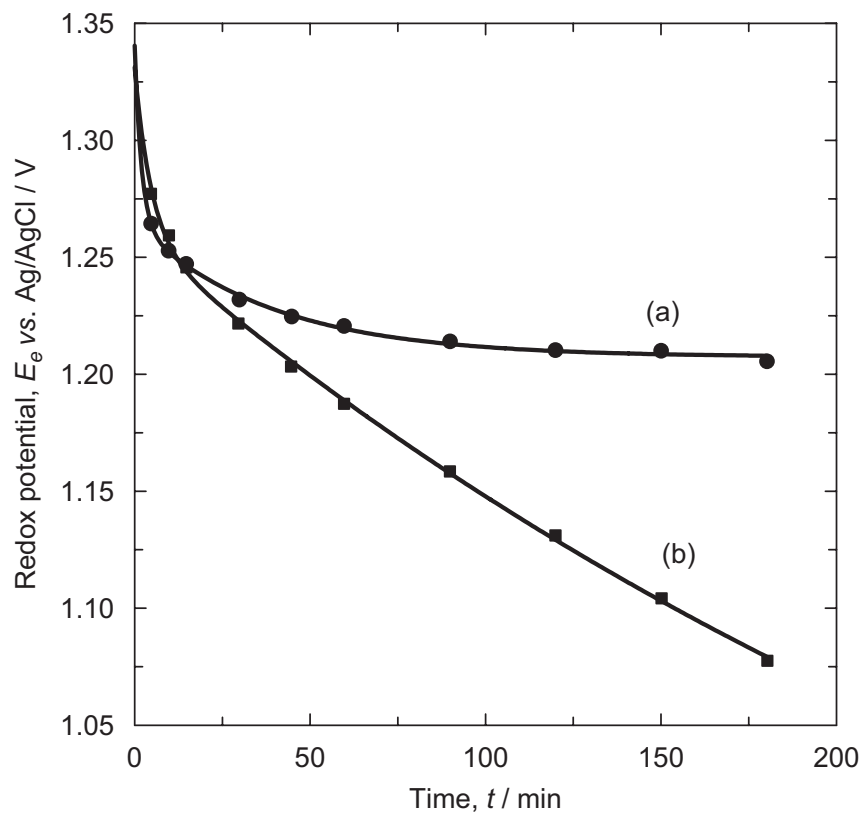

Fig. 5. Redox potential versus time for the reduction of $0.043 \mathrm{~mol} \mathrm{dm}^{-3}$ of $\mathrm{Ce}(\mathrm{IV})$ in $1 \mathrm{moldm}^{-3} \mathrm{H}_{2} \mathrm{SO}_{4}$. (a) (O) Experimental values from the FM01-LC electrochemical reactor with stainless steel 316 cathode, "persalt" production anode and PTFE turbulence promoter at linear flow velocity of $17.7 \mathrm{~cm} \mathrm{~s}^{-1}$ in a batch recycle mode and (b) ( $(\mathbf{a})$ calculated values using Eq. (11).

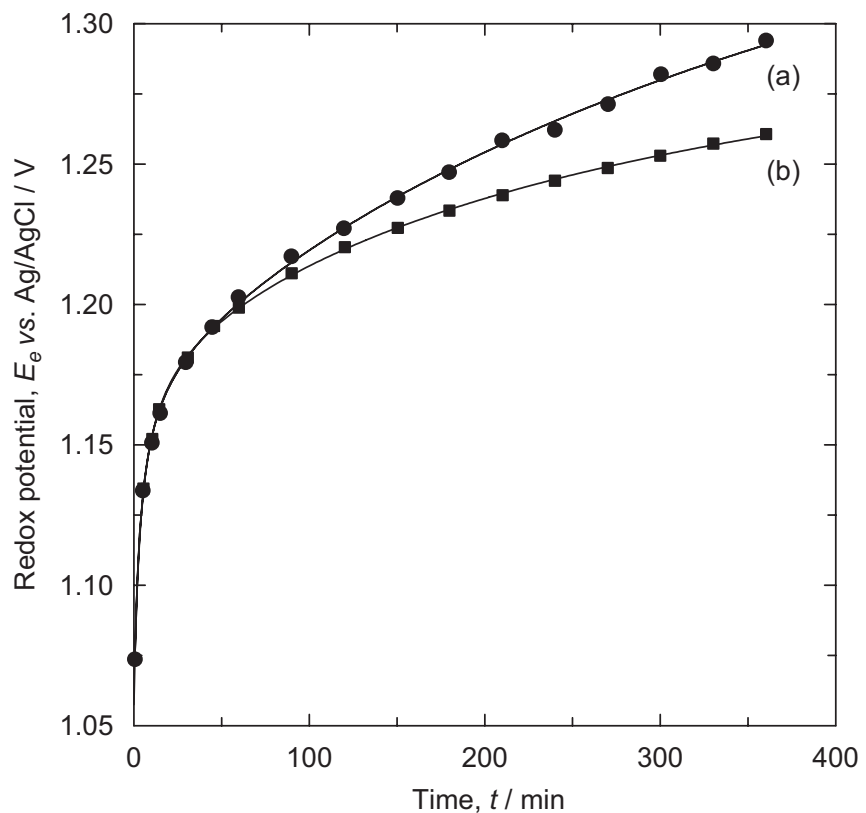

Fig. 6. Redox potential versus time for the oxidation of $0.127 \mathrm{~mol} \mathrm{dm}^{-3}$ of $\mathrm{Ce}$ (III) in $1 \mathrm{~mol} \mathrm{dm}^{-3} \mathrm{H}_{2} \mathrm{SO}_{4}$ and $0.046 \mathrm{~mol} \mathrm{dm}^{-3} \mathrm{Ce}(\mathrm{IV})$. (a) Experimental values obtained using a three-electrode arrangement and two membranes; cathode ICI type 312, two lead anodes, linear flow velocity $17.7 \mathrm{~cm} \mathrm{~s}^{-1}$ in batch recycle mode. (b) (ם) calculated values using Eq. (12).

results were compared with the predicted behaviour and Eq. (11) was used to calculate the first order rate constant by a non-linear, least squares method. This fitting 
procedure has been used in our laboratory for fluid flow studies and is documented in the literature (Clements, 1969; Montillet et al., 1993; Trinidad, 2000).

The redox potential versus time data shown in Fig. 5 were obtained by the application of the simple batch model to the experimental data of concentration versus time during the reduction of $\mathrm{Ce}(\mathrm{IV})$ ions and were analysed by a least squares fit. The apparent, first order rate constant was approximately $0.01 \mathrm{~min}^{-1}$ (Trinidad, 2000). The value found using Eq. (11) and the fitting procedure described in the literature (Clements, 1969; Montillet et al., 1993; Trinidad, 2000), considering the electrolyte redox potential, lead to a value of $0.0344 \mathrm{~min}^{-1}$. A similar difference was found when comparing the case of oxidation of $\mathrm{Ce}(\mathrm{III})$; the

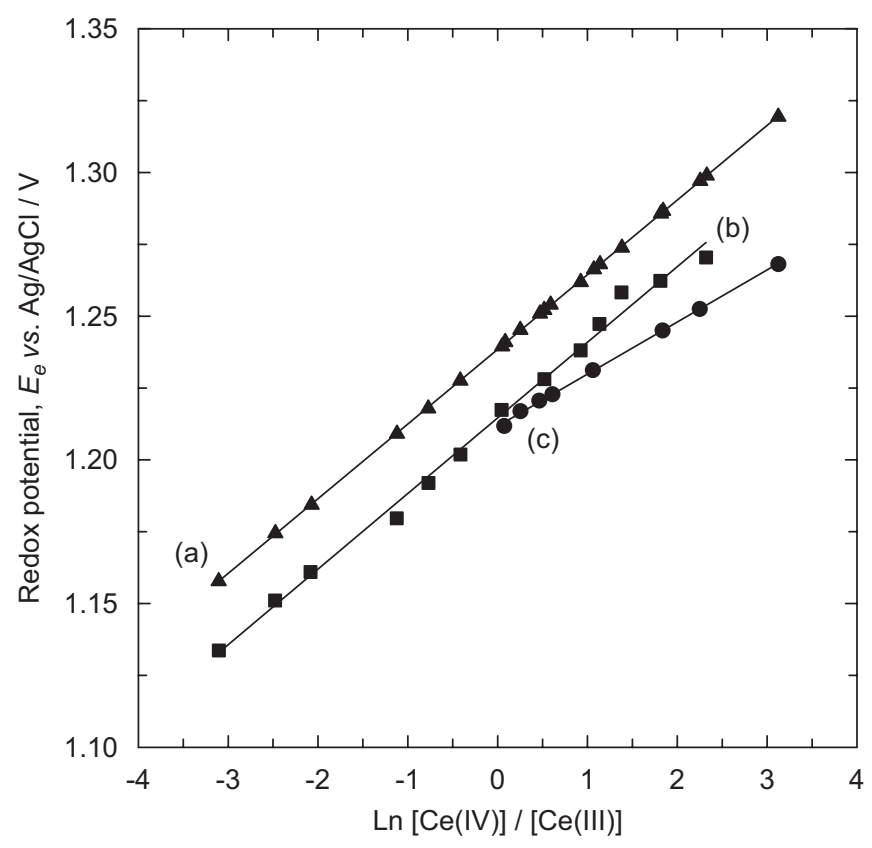

Fig. 7. Nernstian plot of Eq. (2) for: (a) ( $\mathbf{\Delta})$ Nernst theoretical line, (b) ( $\mathbf{\square})$ oxidation of $0.1267 \mathrm{~mol} \mathrm{dm}^{-3} \mathrm{Ce}(\mathrm{III})$ in $1 \mathrm{~mol} \mathrm{dm}^{-3} \mathrm{H}_{2} \mathrm{SO}_{4}$ at the FM01LC electrochemical reactor using a three-electrode arrangement and two membranes; ICI type 312 cathode, two lead anodes and a linear flow velocity of $17.7 \mathrm{~cm} \mathrm{~s}^{-1}$. Initial concentration of $\mathrm{Ce}(\mathrm{IV})=0.06 \mathrm{~mol} \mathrm{dm}^{-3}$. (c) (•) reduction of $0.0435 \mathrm{~mol} \mathrm{dm}^{-3} \mathrm{Ce}(\mathrm{IV})$ in $1 \mathrm{~mol} \mathrm{dm}^{-3} \mathrm{H}_{2} \mathrm{SO}_{4}$ at the FM01-LC electrochemical reactor; cathode: stainless steel 316, anode: persalt production, ICI reference 210 and PTFE turbulence promoter at a linear flow velocity of $17.7 \mathrm{~cm} \mathrm{~s}^{-1}$. first order rate constant calculated by the simple batch model was $0.0085 \mathrm{~min}^{-1}$ while the value found using Eq. (12) and the fitting procedure resulted in a rate constant value of $0.0034 \mathrm{~min}^{-1}$ (Fig. 6). In both cases, the model fitted reasonably well with the experimental values at the beginning of the batch time but as the operation progresses, the discrepancy increased. The potential difference was larger during the reduction of $\mathrm{Ce}(\mathrm{IV})$ ions than during the oxidation of $\mathrm{Ce}(\mathrm{III})$ ions. After $175 \mathrm{~min}$, for example, the difference between the experimental and model data for $\mathrm{Ce}(\mathrm{IV})$ reduction was $150 \mathrm{mV}$ (Fig. 5), whereas, at the same time, the potential difference for $\mathrm{Ce}(\mathrm{III}$ ) oxidation (Fig. 6) was only $25 \mathrm{mV}$. This discrepancy between experimental data and the model prediction could be due to the fact that the redox reaction mechanism for the redox couple $\mathrm{Ce}(\mathrm{IV}) / \mathrm{Ce}(\mathrm{III})$ assumes only $\mathrm{Ce}(\mathrm{III})$ and $\mathrm{Ce}(\mathrm{IV})$ species and one electron transfer in a first order reaction. However, the change in redox potential and the concentration of the electroactive species suggest some degree of solvation and the presence of complex ions (Vetter, 1967). Ce(III) ions exist in solution primarily as $\mathrm{Ce}(\mathrm{III}), \mathrm{CeSO}_{4}^{+}$and to some extent $\mathrm{Ce}\left(\mathrm{SO}_{4}\right)_{2}^{-}$while $\mathrm{Ce}(\mathrm{IV})$ ions tends to form complexes as $\mathrm{Ce}\left(\mathrm{SO}_{4}\right)_{3}^{2-}$. Interaction between species in both states of oxidation is apparent, since it has been found that the ceric ion solubilises the cerous ion (Been and Oloman, 1993). Solvation could also influence the dependence of the redox potential on the nature and concentration of the acid medium and explain the deviation from the ideal Nernstian behaviour.

\subsection{Comparison of Nernst equation plots using redox potential probes}

Fig. 7 shows the Nernst equation plots for the reduction of $\mathrm{Ce}(\mathrm{IV})$ and the oxidation of Ce(III) compared with the theoretical curve from the Nernst Eq. (2) and Table 2 reports the corresponding slopes, the standard electrode potential values and the correlation coefficients. The table shows that the standard potential for the oxidation of $\mathrm{Ce}(\mathrm{III})$ ions using lead electrodes in the three-electrode arrangement and the reduction potential of $\mathrm{Ce}(\mathrm{IV})$ ions at a stainless steel 316 electrode are 1.214 and $1.212 \mathrm{~V}$ versus $\mathrm{Ag} / \mathrm{AgCl}$, respectively. This corresponds to 24 and $26 \mathrm{mV}$ away from the value predicted by the Nernst equation of

Table 2

Standard redox potential and slope for Nernstian expression, see Eq. (2), for various experimental conditions

\begin{tabular}{|c|c|c|c|}
\hline Data source & Observed Nernstian slope, $\frac{R T}{z F} / V$ & $\begin{array}{l}\text { Standard potential, } E^{0} \text { versus } \\
\mathrm{Ag} / \mathrm{AgCl} \text { reference electrode } / V\end{array}$ & Linear correlation coefficient, $r^{2}$ \\
\hline $\begin{array}{l}\mathrm{Ce}(\mathrm{III}) \text { oxidation, see }(\boldsymbol{\square}) \text { in } \\
\text { Fig. } 7\end{array}$ & 0.026 & 1.214 & 0.998 \\
\hline $\begin{array}{l}\text { Cerium(IV) reduction, see }(\bullet) \\
\text { in Fig. } 7\end{array}$ & 0.018 & 1.212 & 0.993 \\
\hline $\begin{array}{l}\text { Cerium(IV) reduction, see ( } \mathbf{\square}) \\
\text { in Fig. } 8\end{array}$ & 0.028 & 1.180 & 0.982 \\
\hline
\end{tabular}


$1.238 \mathrm{~V}$ versus $\mathrm{Ag} / \mathrm{AgCl}$, respectively. Table 2 also shows the value of the standard potential obtained from the Nernstian plot shown on Fig. 8 for the reduction of Ce(IV) ions on an 100 ppi RVC electrode. On this electrode, the standard potential value obtained from the experiment was $1.18 \mathrm{~V}$ versus $\mathrm{Ag} / \mathrm{AgCl}$ which corresponds to $58 \mathrm{mV}$ away from the theoretical value. Despite the acceptable values of the correlation coefficient presented in Table 2, the pseudoNernstian behaviour of this system indicates a clear deviation from the thermodynamically standard value $E_{\mathrm{e}}^{\mathrm{o}}$. Indeed, complexation of the redox species and solvent interactions affect the redox potential as it depends on the activity coefficients that, in turn, vary with the ionic strength of the solution (Paulenova et al., 2002). The similarity between the theoretical and experimental values of the slope for the oxidation of Ce(III) ions suggest a single electron transfer process whereas the larger differ-

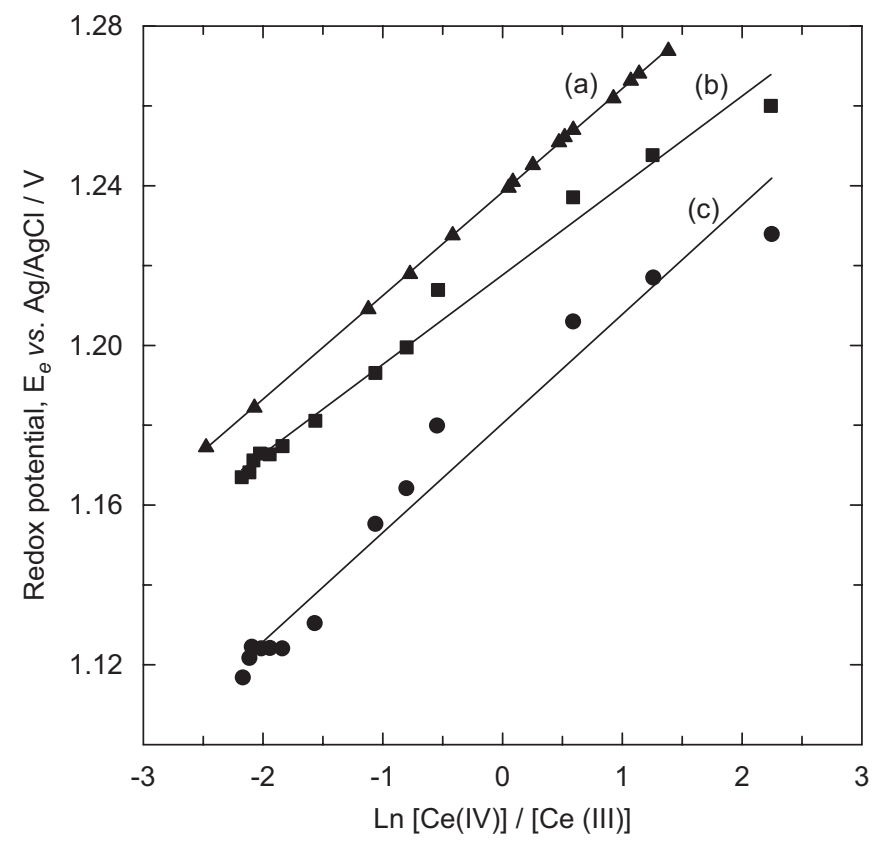

Fig. 8. Comparison of Nernstian plots, Eq. (2), for the reduction of $0.0388 \mathrm{~mol} \mathrm{dm}^{-3} \mathrm{Ce}(\mathrm{IV})$ in $1 \mathrm{~mol} \mathrm{dm}^{-3} \mathrm{H}_{2} \mathrm{SO}_{4}$, at the FM01-LC electrochemical reactor. Cathode: 100 ppi RVC, anode: oxygen evolution ICI reference 304. Mean linear flow velocity $17.7 \mathrm{~cm} \mathrm{~s}^{-1}$. Probes: (a) theory, (b) (ם) Pt electrode versus $\mathrm{Ag} / \mathrm{AgCl}$ and (c) (๑) glassy carbon electrode versus SCE. ence of the slope value from the reduction of $\mathrm{Ce}(\mathrm{IV})$ suggests a more complex electron transfer.

The redox potential during the reduction of $\mathrm{Ce}(\mathrm{IV})$ was measured with a commercial platinum redox probe and a probe consisted on a glassy carbon rod coupled with a standard calomel electrode (SCE). The values obtained with these two probes are shown in Fig. 8. Although the redox potential values measured with the two probes indicate that at positive potentials the concentration of $\mathrm{Ce}(\mathrm{IV})$ ions increases, the two values differ by around $50 \mathrm{mV}$ when the concentration of $\mathrm{Ce}(\mathrm{IV})$ ions is 1000 times lower than the concentration of $\mathrm{Ce}(\mathrm{III})$ ions. At similar concentration, the redox potential difference is still $37 \mathrm{mV}$. The figure shows that the redox potential values obtained with the commercial platinum probe are closer to the theoretical redox potential values especially at low concentrations of $\mathrm{Ce}(\mathrm{IV})$. Although the redox potential probes provided slightly different potential values, the values reflect the changes in concentration of the electroactive species and the different catalytic effects of each material (Pt and carbon) on the redox couple.

Table 3 shows the values of the slope and standard potential found when the commercial platinum probe and the glassy carbon rod during the oxidation of $\mathrm{Ce}(\mathrm{III})$ were used. The table shows that the standard potential values for the $\mathrm{Pt}$ and $\mathrm{C}$ differ from the value obtained by the Nernst equation by 21 and $58 \mathrm{mV}$, respectively. Despite these deviations, the results suggest that the pseudo-Nernstian behaviour of this system can be monitored on-line with acceptable errors in the concentration as a simple technique.

\section{Conclusions}

1. The Nernst equation has been used to express electrolyte redox potential as function of batch time in an electrochemical batch recycle system, with current efficiency and charge passed as parameters.

2. Appropriate manipulation of the Nernst equation, Faraday's laws of electrolysis and a mass balance leads to expressions that can be used to estimate kinetic parameters.

3. The $\mathrm{Ce}(\mathrm{IV}) / \mathrm{Ce}$ (III) redox system has been used to compare experimental conditions with those predicted by theory. In general, the theoretical prediction are useful for a first order approximation at small times

Table 3

Comparison of the slope and standard potential of the curves in Fig. 8 for two electrode probes

\begin{tabular}{llcc}
\hline Electrode probe & $\begin{array}{l}\text { Pseudo-Nernstian slope/ } \\
V \text { decade }^{-1}\end{array}$ & $\begin{array}{l}\text { Standard potential, } E^{0} \text { versus } \\
\text { SHE/V }\end{array}$ & $\begin{array}{l}\text { Standard potential, } E^{0} \text { versus } \\
\mathrm{Ag} / \mathrm{AgCl} / V\end{array}$ \\
\hline $\mathrm{Pt}$ & 0.023 & 1.422 & 1.225 \\
$\mathrm{C}$ & 0.028 & 1.385 & 1.188 \\
(Nernst theoretical value) & $(0.026)$ & $(1.443)$ & $(1.246)$ \\
\hline
\end{tabular}

(a) Pt electrode versus $\mathrm{Ag} / \mathrm{AgCl}$ and (b) glassy carbon rod versus SCE during the reduction of $0.0388 \mathrm{~mol} \mathrm{dm}^{-3} \mathrm{Ce}(\mathrm{IV})$ in $1 \mathrm{~mol} \mathrm{dm}^{-3} \mathrm{H}_{2} \mathrm{SO}_{4}$ in the $\mathrm{FM}_{01}$ LC electrochemical reactor. Three-electrode arrangement: a 100 ppi RVC cathode with a Nafion membrane at each side and two anodes for oxygen evolution (type ICI 304). Mean linear flow velocity, $17.7 \mathrm{~cm} \mathrm{~s}^{-1}$. 
(and hence at low values of fractional conversion); however, significant differences between experimental and predicted values have been found at longer electrolysis times. This is partly attributable to the presence of solvated species and complex formation involving $\mathrm{Ce}(\mathrm{III})$ and $\mathrm{Ce}(\mathrm{IV})$ species, which modify the actual concentration of $\mathrm{Ce}$ (III) and $\mathrm{Ce}(\mathrm{IV})$ together with the assumption of a simple, first order reaction. Furthermore, the redox potential depends on the activity coefficients of the ionic species that are affected by the ionic strength of the solution.

4. The electrolyte redox potential is a useful, if approximate, method to predict concentration versus time in a simple redox system.

\section{Acknowledgements}

The authors are grateful for the financial support provided by a European Union grant (to Pedro Trinidad) and to EA Technology for provision of equipment.

\section{References}

Bard, A.J., Faulkner, L.R., 2001. Electrochemical Methods: Fundamentals and Applications, second ed. Wiley, New York.

Been, J., Oloman, C.W., 1993. Journal of Applied Electrochemistry 23, 1301.

Bockris, J.O’M., Reddy, A.K.N., 1998. Modern Electrochemistry, second ed. Plenum Press, New York.

Brown, C.J., Pletcher, D., Walsh, F.C., Hammond, J.K., Robinson, D., 1992. Journal of Applied Electrochemistry 22, 613.

Brown, C.J., Pletcher, D., Walsh, F.C., Hammond, J.K., Robinson, D., 1994. Journal of Applied Electrochemistry 24, 95.

Brown, C.J., Walsh, F.C., Pletcher, D., 1995. Transactions of the Institution of the Chemical Engineers 73, 196.

Chang, C.-N., Cheng, H.B., Chao, A.C., 2004. Environmental Science and Technology 38, 1807.

Chung, Y.H., Park, S.-M., 2000. Journal of Applied Electrochemistry 30, 685.

Clements, W.C., 1969. Chemical Engineering Science 24, 957.

Diatloff, E., Asher, C.J., Smith, F.W., 1999. Materials Science Forum 315, 354.

Ford, W.P.J., Walsh, F.C., Whyte, I., 1992. Institution of the Chemical Engineering Symposium Series 127, 111.

He, Y.-W., Loh, C.-S., 2000. Plant Science 159, 117.
High Capacity Electrical Storage \& Power Conditioning Units. [online] Reno Nevada. Available at:〈http://plurionsystems.com〉 (accessed 18.06.07).

Hu, X., Ding, Z., Chen, Y., Wang, X., Dai, L., 2002. Chemosphere 48, 621.

Jain, V.K., Handa, A., Sait, S.S., Shrivastav, P., Agrawal, Y.K., 2001. Analytical Chimica Acta 429, 237.

Kiekens, P., Steen, L., Donche, H., Temmerman, E., 1981. Electrochimica Acta 26, 841.

Levenspiel, O., 1972. Chemical Reaction Engineering, second ed. Wiley, New York.

Liu, W., Huang, Y., 2004. Analytica Chimica Acta 506, 183.

Liu, Y., Xia, X., Liu, H., 2004. Journal of Power Sources 130, 299.

Montillet, A., Comiti, J., Legrand, J., 1993. Journal of Applied Electrochemistry 23, 1045.

Nevell, T.G., Walsh, F.C., 1992. Transactions of the Institute of Metal Finishing 70, 144.

Ottewill, G.A., Walsh, F.C., 1992. Transactions of the Institute of Metal Finishing 70, 141.

Paulenova, A., Creager, S.E., Navratil, J.D., Wei, Y., 2002. Journal of Power Sources 109, 431.

Pletcher, D., 1991. A First Course in Electrode Processes. The Electrochemical Consultancy, Romsey.

Pletcher, D., Walsh, F.C., 1993. Industrial Electrochemistry, second ed. Blackies A \& P, Glasgow.

Ponce de León, C., Frías-Ferrer, A., González-García, J., Szánto, D.A., Walsh, F.C., 2006. Journal of Power Sources 160, 716.

Ralph, T.R., Hitchman, M.L., Millington, J.P., Walsh, F.C., 2005. Journal of the Electrochemical Society 152, D54.

Seames, W.S., Wendt, J.O.L., 2000. Advances in Environmental Research 4,45 .

Shuai, Q., Qin, Y., Hu, B., Xiong, H., Jiang, Z., 2000. Analytical Science $16,957$.

Sparks, D.L., 1995. Environmental Soil Chemistry. Academic Press, San Diego, CA.

Trinidad, P., 2000. Fluid flow, mass transport and electrosynthesis studies in filter-press electrochemical reactors. Ph.D. Thesis, University of Portsmouth, UK.

Trinidad, P., Walsh, F.C., 1999. Institution of Chemical Engineering Symposium Series 145, 281.

Vetter, K.J., 1967. Electrochemical Kinetics, Theoretical and Experimental Aspects. Academic Press, New York.

Vogel, A.I., 1989. Textbook of Quantitative Inorganic Analysis, fifth ed. Wiley, New York.

Walker, A.T.S., Wragg, A.A., 1977. Electrochimica Acta 22, 1129.

Walsh, F.C., 1991. Bulletin of Electrochemistry 7, 481.

Walsh, F.C., 1992. Transactions of the Institute of Metal Finishing 69, 111.

Walsh, F.C., 1993. A First Course in Electrochemical Engineering. The Electrochemical Consultancy, Romsey.

Xu, Z., 2000. Materials Research Bulletin 35, 1261. 